\title{
Fatty Acid Contents of Gamma Irradiated Sesame (Sesamumindicum L.) Peanut (Arachishypogaea L.) and Sunflower (Helianthus annuus L.) Seeds
}

\author{
Mahfouz Al-Bachir
}

Department of Radiation Technology, Atomic Energy Commission of Syria, Damascus, Syria

Correspondence to:

Mahfouz Al-Bachir

Department of Radiation Technology

Atomic Energy Commission of Syria, Damascus

P.O. Box 6091, Syria Arab Republic

Tel: 00963112132580

Fax: 00963116112289

E-mail: ascientific@aec.org.sy

Received: November 24, 2016

Accepted: February 02, 2017

Published: February 06, 2017

Citation: Al-Bachir M. 2017. Fatty Acid Contents of Gamma Irradiated Sesame (Sesamumindicum L.) Peanut (Arachishypogaea L.) and Sunflower (Helianthus annuus L.) Seeds. I Food Chem Nanotechnol 3(1): 31-37.

Copyright: (C) $2017 \mathrm{Al}-\mathrm{Bachir}$. This is an Open Access article distributed under the terms of the Creative Commons Attribution 4.0 International License (CC-BY) (http://creativecommons. org/licenses/by/4.0/) which permits commercial use, including reproduction, adaptation, and distribution of the article provided the original author and source are credited.

Published by United Scientific Group

\begin{abstract}
Fatty acids composition are an important attribute in oil. The present study aimed to evaluate three selected sources of oil namely, sesame (Sesamum indicum L.) peanut (Arachis hypogaea L.) and sunflower (Helianthus annuus L.). Oil were extracted from seeds produced in Syria and irradiated with 3,6 and $9 \mathrm{kGy}$ of gamma-irradiation to assess the variability in fatty acid composition and to determine the relationship between irradiation and certain fatty acids. Results demonstrated that sesame, sunflower and peanut oils are of unsaturated type and contain mainly the oleic C18:1 and linoleic C18:2 fatty acids. Irradiation of seeds with medium doses ( 3 to $9 \mathrm{kGy}$ ) did not significantly affect the fatty acids contents. However, the un-saturated, saturated fatty acids, and the ratio of saturated to un-saturated fatty acids (TU/TS) were altered upon irradiation. These changes were significant for sesame and sunflower oils, but not for peanut oil.
\end{abstract}

\section{Keywords}

Fatty acids, Gamma irradiation, Peanut oil, Sesame oil, Sunflower oil

\section{Introduction}

Oils from vegetables are complex mixtures that contain several compounds and are made up of free fatty acids (FFA), triacylglycerols, glycolipids, diacylglycerols, phospholipids, and other minor components [1]. Vegetable oil usage is largely centered on the type of fatty acids present in the oil and these fatty acids fall into various lipid categories [1,2].

Fat is an important dietary component, which affects both growth and health. Even though polyunsaturated fatty acids (PUFAs) have been investigated to have health benefits [3]. Compositions of vegetable oils are valuable information in understanding their functional, quality and nutritional properties. Increasing the content of saturated fatty acids can enhance stability with the concomitant increase of the proportion of solid fat and the melting temperature [4]. Oilseeds vary widely in their fatty acids composition, but tend to be rich in monounsaturated fatty acids (MUFAs) (e.g. peanuts) or PUFA (e.g. sunflower seeds) [5]. Also, the composition of oleic, linoleic and linolenic acids in oil has an effect on the oxidative stability [6].

Gamma-irradiation has wide range of applications in food technology [7-9]. Irradiation causes molecular changes, among which the formation of free radicals is one of the most important for a high fat content foods that in turn can change the fatty acid composition and consequently the fat functional benefits [9-13]. The increase in free fatty acid was observed in beans and edible oils irradiated in the range of 1.0-20 kGy [14]. Polyunsaturated fatty acids are susceptible 
to oxidation by radical processes. It is well known that free radicals are formed in food by ionizing irradiation, and the ratio of unsaturated to saturated total fatty acids (TU/TS) was significantly altered upon irradiation [7].

Keeping in the interest of irradiation importance, the present study aimed at the investigation of gamma-radiation effects of medium doses (3, 6 and $9 \mathrm{kGy})$ on the fatty acid contents of sesame sunflower and peanut oils.

\section{Materials and Methods}

\section{Treatments and analysis performed}

Samples of sesame (Sesamum indicum L.) sunflower (Helianthus annuus L.) and peanut (Arachis hypogaea L.) seeds of Syrian cultivars were purchased from local supermarkets and special shops in Damascus, the capital of Syria. The seeds were harvested during 2013/2014 growing season, and stored at room temperature $20-25{ }^{\circ} \mathrm{C}$ under relative humidity ( $\mathrm{RH}$ ) of $50-70 \%$. Then seeds were weighed as in the sampling plan and transferred into polyethylene pouches for irradiation. Each pouch of seeds $(250 \mathrm{~g})$ was considered as a replicate. At the same production years $(2014)$, the samples were exposed to gamma-radiation at doses of 3, 6 and $9 \mathrm{kGy}$ in a ${ }^{60} \mathrm{CO}$ package irradiator. Samples were irradiated at place with a dose rate of $7.775 \mathrm{kGy} \mathrm{h}^{-1}$, at room temperature and atmospheric pressure [8]. Oils from control and irradiated sesame, sunflower and peanut seeds after grinding were extracted by the manual Soxhlet apparatus (Scientific Apparatus Manufacturing Company, Glas-Col Combo Mantle, USA) for $16 \mathrm{~h}$, using distilled AR (analytical grade) n-hexane as a solvent [15]. Oils were decanted and immediately transferred into dark glass bottles and stored at room temperature $\left(20-25^{\circ} \mathrm{C}\right)$ under relative humidity $(\mathrm{RH})$ of $50-70 \%$ for analysis. The assessment of saturated and unsaturated fatty acid content using gas chromatography of oils extracted from irradiated and nonirradiated seeds samples were performed immediately after irradiation, and after 6 and 12 months of storage

\section{Fatty acids (FA) determination}

The lipid fraction of sesame, sunflower and peanut oil samples was extracted and FA methyl esters (FAME) were prepared [9]. The FAs content was determined by gas chromatography in a GC-17 a Shimadzu chromatograph (Shimadzu Corp., Koyoto, Japan) equipped with a flame ionization detector and a capillary column (CBP20-S25- 050, Shimadzu,Australia). The selected chromatographic conditions were; oven temperature $190{ }^{\circ} \mathrm{C}$, detector temperature $250{ }^{\circ} \mathrm{C}$, injector temperature $220^{\circ} \mathrm{C}$; N2 was used as a carrier gas with split ratio 29:1, the sample volume injected was $1 \mu 1$. Peak areas were integrated and converted to FA percentages (direct area normalization) by means of the CLASS - VP 4.3 program (Shimadzu Scientific Instruments, Inc., Columbia, MD). The FA identification, prior to GC analysis, was carried out by retention times and by addition of standards from Fluka Chemie, (Bches SG. Switzerland) and a reference laboratory.

\section{Statistical analysis}

The four treatments were distributed in a completely randomized design with three replicates. Data were subjected to variance test analysis (ANOVA) using the SUPERANOVA computer package (Abacus Concepts Inc, Berkeley, CA, USA; 1998). The $p$ value of less than 0.05 was considered statistically significant. The degree of significance was denoted as: $p<0.05^{*}$, $\mathrm{p}<0.01^{* *}[16]$.

\section{Results and Discussion}

Effect of gamma-irradiation on fatty acid of sesame seed oil

The fatty acid content of total lipid extracted from non-irradiated sesame seed oil is shown in Figure 1. Also the percentage of individual fatty acid compositions of total lipids extracted from non-irradiated and irradiated sesame seeds at different doses and several storage times are shown in Table 1. The major of fatty acids in oil extracted from non-irradiated control samples of local cultivated sesame seeds were palmitic (C16:0) (9.08\%) stearic (C18:0) (5.30\%) oleic (C18:1) (42.33\%) and linoleic (C18:2) (42.85\%) acids. The present findings are in harmony with previous studies, indicating that all sesame seed lipids had oleic and linoleic acids as the most predominant ones among the unsaturated fatty acids. Similarly, palmitic and stearic acid are the most prevalent among the saturated acids in sesame seed oil [17]. Sesame oils are highly resistant to oxidative deterioration even though oleic and linoleic acids are the predominant fatty acids of sesame oil, about $80 \%$ of its total [18].

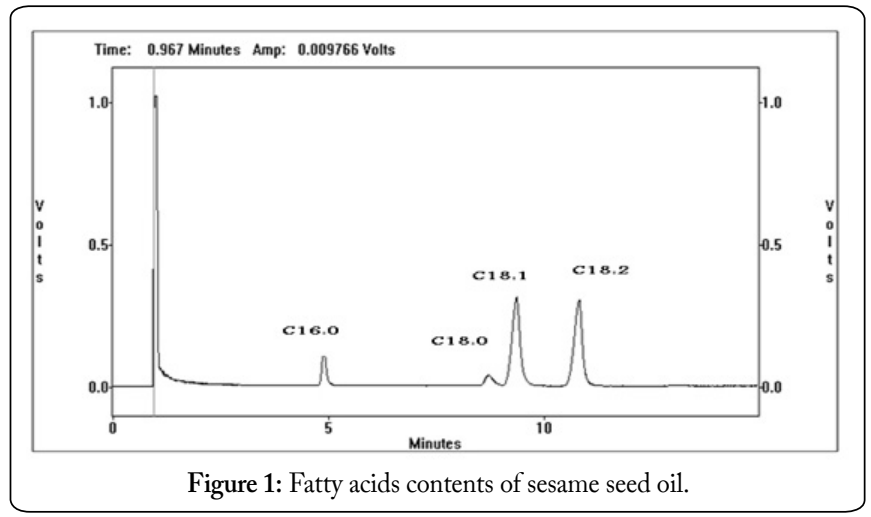

Results of the current study are somehow similar to that of Nzikou et al. [19] which indicated that the France sesame seed oil contained palmitic (8.58\%) stearic (5.44\%) oleic (38.84\%) and linoleic (46.26\%) acids, (14.90\%) as saturated and (85.62\%) as un-saturated fatty acids. Compared to the Sudan variety (white spices of sesame) studied by Elleuch et al. [20], the Syrian extracted sesame seed oil had higher amounts of linoleic acid ( 42 against 35\%) and lower amount of oleic acid ( 42 against $\sim 44 \%)$. However, fatty acid composition varies considerably depending on where the crop was grown. It has been shown that environmental factors play an important role in fatty acid composition [21].

The presented data showed an increase in the percentage of saturated fatty acids, that was insignificant $(p>0.05)$ for $\mathrm{C} 16: 0$ and significant $(\mathrm{p}<0.05)$ for $\mathrm{C} 18: 0$, and significant $(\mathrm{p}<0.05)$ decrease in the polyunsaturated (PUFA) fatty acids (C18:2) with an irradiation dose of $9 \mathrm{kGy}$. Irradiation (7.5 
$\mathrm{kGy}$ ) caused a significant gradual decrease in the unsaturated fatty acid content increase as irradiation dose increased in sesame seeds $[7,17]$. In addition, UV-irradiation obviously destroyed the unsaturated fatty acids in peanut oil at various degrees, and their decreases were time dependent [22]. On the other hand, Barreira et al. [23] reported that radiation dose of $3 \mathrm{kGy}$ did not induce any differences on monounsaturated (MUFA) and polyunsaturated (PUFA) fatty acids. Also, Mexis et al. [24] reported no statistically significant ( $p>0.05)$ change in unsaturated fatty acids of almond kernels irradiated with a dose up to $7 \mathrm{kGy}$.

\begin{tabular}{|c|c|c|c|c|c|}
\hline Treatment & Control & $3 \mathrm{KGY}$ & $6 \mathrm{KGY}$ & $9 \mathrm{KGY}$ & $\begin{array}{l}\text { P- } \\
\text { level }\end{array}$ \\
\hline \multicolumn{6}{|c|}{ Storage period/(Months) $\quad$ C16:0 } \\
\hline $\mathbf{0}$ & $9.08 \pm 0.10^{2 \mathrm{~A}}$ & $9.09 \pm 0.01^{\mathrm{AA}}$ & $9.04 \pm 0.05^{\mathrm{aA}}$ & $9.14 \pm 0.03^{\text {aA }}$ & NS \\
\hline 6 & $9.04 \pm 0.03^{\mathrm{aA}}$ & $9.03 \pm 0.02^{\mathrm{aA}}$ & $8.88 \pm 0.09^{\mathrm{bB}}$ & $8.99 \pm 0.03^{\mathrm{aB}}$ & $*$ \\
\hline 12 & $8.80 \pm 0.06^{\mathrm{aB}}$ & $8.82 \pm 0.09^{\mathrm{aB}}$ & $8.78 \pm 0.02^{\mathrm{aB}}$ & $8.76 \pm 0.08^{\mathrm{aC}}$ & NS \\
\hline P-level & ** & $* *$ & $* *$ & *** & \\
\hline \multicolumn{6}{|c|}{ C18:0 } \\
\hline $\mathbf{0}$ & $5.30 \pm 0.02^{\mathrm{bB}}$ & $5.33 \pm 0.05^{\mathrm{bB}}$ & $5.44 \pm 0.01^{\mathrm{aB}}$ & $5.48 \pm 0.01^{\mathrm{aB}}$ & $* *$ \\
\hline 6 & $5.30 \pm 0.03^{\mathrm{aB}}$ & $5.36 \pm 0.03^{\mathrm{aB}}$ & $5.30 \pm 0.03^{\mathrm{ac}}$ & $5.34 \pm 0.01^{\mathrm{aC}}$ & $*$ \\
\hline 12 & $5.47 \pm 0.03^{\mathrm{bA}}$ & $5.50 \pm 0.02^{\mathrm{abA}}$ & $5.55 \pm 0.05^{\mathrm{aA}}$ & $5.52 \pm 0.02^{\mathrm{bA}}$ & NS \\
\hline P-level & $* *$ & *** & $* *$ & $* *$ & \\
\hline \multicolumn{6}{|c|}{ C18:1 } \\
\hline $\mathbf{0}$ & $42.33 \pm 0.11^{\mathrm{bB}}$ & $42.30 \pm 0.02^{\mathrm{bB}}$ & $42.26 \pm 0.06^{\mathrm{BB}}$ & $42.47 \pm 0.04^{\mathrm{aB}}$ & $*$ \\
\hline 6 & $42.38 \pm 0.08^{\mathrm{bcB}}$ & $42.35 \pm 0.03^{\mathrm{cB}}$ & $42.51 \pm 0.03^{\mathrm{aA}}$ & $42.45 \pm 0.03^{\mathrm{abB}}$ & $* *$ \\
\hline 12 & $42.82 \pm 0.08^{\mathrm{bA}}$ & $43.01 \pm 0.08^{\mathrm{aA}}$ & $42.60 \pm 0.06^{\mathrm{cA}}$ & $42.74 \pm 0.04^{\mathrm{bA}}$ & $* *$ \\
\hline P-level & $* *$ & $* *$ & $* *$ & $* *$ & \\
\hline \multicolumn{6}{|c|}{ C18:2 } \\
\hline 0 & $42.85 \pm 0.01^{\mathrm{aB}}$ & $42.85 \pm 0.06^{\mathrm{AA}}$ & $42.79 \pm 0.03^{\mathrm{aB}}$ & $42.47 \pm 0.03^{\mathrm{bC}}$ & $* *$ \\
\hline 6 & $42.90 \pm 0.04^{\mathrm{AA}}$ & $42.88 \pm 0.05^{\mathrm{aB}}$ & $42.92 \pm 0.06^{\mathrm{aA}}$ & $42.84 \pm 0.02^{2 \mathrm{~A}}$ & NS \\
\hline 12 & $42.50 \pm 0.02^{\mathrm{bB}}$ & $42.29 \pm 0.06^{\mathrm{cB}}$ & $42.66 \pm 0.04^{\mathrm{ac}}$ & $42.57 \pm 0.06^{6 \mathrm{~B}}$ & $* *$ \\
\hline P-level & $* *$ & $* *$ & $* *$ & $* *$ & \\
\hline \multicolumn{6}{|c|}{$\begin{array}{l}\text { abc Means values in the same row not sharing a superscript are significantly } \\
\text { different. } \\
\text { ABC Means values in the same column not sharing a superscript are } \\
\text { significantly different. } \\
\text { NS: not significant. } \\
\text { * Significant at } \mathrm{p}<0.05 \text {. } \\
\text { * Significant at } \mathrm{p}<0.01 \text {. }\end{array}$} \\
\hline
\end{tabular}

The relative quantities of total un-saturated fatty acids (TUFA) and total saturated fatty acids (TSFA) in oil are important issues for health and nutrition. The ratio of TUFA to saturated TSFA (TUFA/TSFA) is important in projecting the detrimental effects of dietary fats [25]. The ratio between total unsaturated fatty acids and saturated ones (TU/TS) was 5.96 for the control sesame oil, while it decreased gradually along with irradiation doses (Table 2).

\section{Effects of gamma-irradiation on fatty acid of sunflower oil}

Compositions and differences related with irradiation doses and storage times; such as palmitic (C16:0), stearic
(C18:0), oleic (C18:1) and linoleic (C18:2) fatty acids, and total saturated and unsaturated fatty acids were statistically analyzed. Other fatty acids were not analyzed since they do not indicate a significant difference regarding the irradiation exposure dose and proportional side.

Table 2: Effects of gamma-irradiation and storage periods on total saturated fatty acids (SFA) and unsaturated fatty acids (USFA) of Sesame oil.

\begin{tabular}{|c|c|c|c|c|c|}
\hline Treatment & Control & $3 \mathrm{KGY}$ & $6 \mathrm{KGY}$ & $9 \mathrm{KGY}$ & $\begin{array}{l}\text { P- } \\
\text { level }\end{array}$ \\
\hline \multicolumn{3}{|c|}{ Storage period/(Months) } & \multicolumn{3}{|l|}{ SFA } \\
\hline 0 & $14.38 \pm 0.11^{\mathrm{bA}}$ & $14.42 \pm 0.05^{\mathrm{bA}}$ & $14.48 \pm 0.06^{\mathrm{bA}}$ & $14.61 \pm 0.03^{\mathrm{aA}}$ & $* *$ \\
\hline 6 & $14.34 \pm 0.05^{\mathrm{aA}}$ & $14.39 \pm 0.04^{\mathrm{aA}}$ & $14.18 \pm 0.07^{\mathrm{bC}}$ & $14.34 \pm 0.04^{\mathrm{aB}}$ & ** \\
\hline 12 & $14.27 \pm 0.09^{\mathrm{aA}}$ & $14.33 \pm 0.07^{\mathrm{aA}}$ & $14.33 \pm 0.04^{\mathrm{aB}}$ & $14.27 \pm 0.06^{\mathrm{aB}}$ & NS \\
\hline P-level & NS & $* *$ & $* *$ & $* *$ & \\
\hline \multicolumn{6}{|c|}{ USFA } \\
\hline 0 & $85.62 \pm 0.11^{\mathrm{bB}}$ & $85.58 \pm 0.05^{\mathrm{bA}}$ & $85.52 \pm 0.06^{\mathrm{bC}}$ & $86.39 \pm 0.04^{2 A}$ & ** \\
\hline 6 & $85.66 \pm 0.05^{\mathrm{bAB}}$ & $85.61 \pm 0.04^{\mathrm{bA}}$ & $85.82 \pm 0.07^{\mathrm{AA}}$ & $85.67 \pm 0.04^{\mathrm{bB}}$ & ** \\
\hline 12 & $85.73 \pm 0.09^{\mathrm{aA}}$ & $85.68 \pm 0.07^{\mathrm{A} A}$ & $85.67 \pm 0.04^{\mathrm{aB}}$ & $85.73 \pm 0.06^{\mathrm{aB}}$ & NS \\
\hline P-level & NS & $* *$ & $* *$ & $* *$ & \\
\hline \multicolumn{6}{|c|}{ USFA/SFA } \\
\hline 0 & $5.96 \pm 0.05^{\mathrm{aA}}$ & $5.94 \pm 0.02^{\mathrm{aB}}$ & $5.91 \pm 0.03^{\mathrm{aC}}$ & $5.84 \pm 0.02^{\mathrm{bC}}$ & $*$ \\
\hline 6 & $5.98 \pm 0.02^{\mathrm{bA}}$ & $5.95 \pm 0.02^{\mathrm{bB}}$ & $6.05 \pm 0.04^{\mathrm{aA}}$ & $5.98 \pm 0.02^{\mathrm{bB}}$ & *** \\
\hline 12 & $6.01 \pm 0.04^{\mathrm{bA}}$ & $6.98 \pm 0.04^{\text {aA }}$ & $5.98 \pm 0.02^{\mathrm{bB}}$ & $6.01 \pm 0.03^{\mathrm{bA}}$ & NS \\
\hline P-level & NS & $* *$ & $* *$ & $* *$ & \\
\hline \multicolumn{6}{|c|}{$\begin{array}{l}\text { abc Means values in the same row not sharing a superscript are significantly } \\
\text { different. } \\
\text { ABC Means values in the same column not sharing a superscript are } \\
\text { significantly different. } \\
\text { NS: not significant. } \\
\text { * Significant at } \mathrm{p}<0.05 \text {. } \\
\text { * Significant at } \mathrm{p}<0.01 \text {. }\end{array}$} \\
\hline
\end{tabular}

Data in Figure 2 and Table 3 show that oils extracted from non-irradiated (control) sunflower seeds contained (6.09\%) palmitic acid (3.17\%) stearic acid (43.52\%) oleic acid and (48.19\%) linoleic acid which comprised $100 \%$ of total fatty acids. Fatty acid composition of sunflower seed oil has been reported by a number of scientists to vary with planting location and with climatic conditions during the growing season. Sunflower oil content of fatty acids presented in this study is similar to that of Samarth and Mahanwar [26], Makhoul et al. [27] and Hosein et al. [28] who reported that sun flower oil contained palmitic (5.81-8.0\%) stearic (3.35$6.3 \%)$ oleic (23.81-42.6\%) and linoleic (46-65.73\%) acids.

Gamma-irradiation caused a noticeable alteration in the unsaturated and saturated fatty acid composition of sunflower seed oil which showed a decrease $(\mathrm{p}<0.05)$ in the relative amounts of palmitic acid (C16:0) at a 6 and $9 \mathrm{kGy}$, and an increase $(\mathrm{p}<0.05)$ in the linoleic acid $(\mathrm{C} 18: 2)(\mathrm{p}<0.05)($ Table 2$)$. The present findings agree with previous studies, where it was found that gamma-irradiation had some effects on the physical and chemical composition of soybeans [29]. In contrast to our results, the fatty acid linoleic C18:2 is considered to be the most affected one by gamma-radiation which was decreased by over $2 \%$ followed by oleic $\mathrm{C} 18: 1$ when irradiated at $7.5 \mathrm{kGy}$ [7]. Finally Al-Bachir, [11] indicated that, SFA and USFA of 
almond were not affected by irradiation with irradiation dose up to $3 \mathrm{kGy}$.

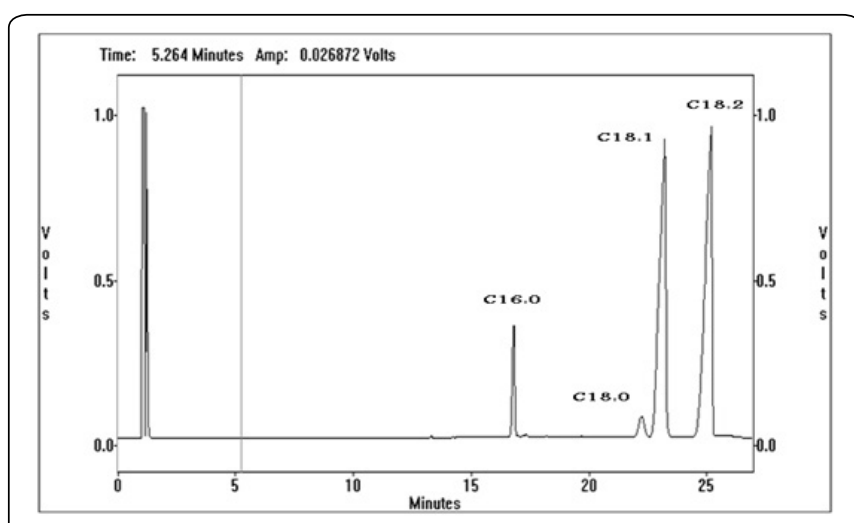

Figure 2: Fatty acids contents of sunflower seed oil.

Table 3: Effects of gamma-irradiation and storage periods on fatty acids content (\%) of Sunflower oil.

\begin{tabular}{|c|c|c|c|c|c|}
\hline Treatment & Control & $3 \mathrm{KGY}$ & $6 \mathrm{KGY}$ & $9 \mathrm{KGY}$ & $\begin{array}{l}\text { P- } \\
\text { level }\end{array}$ \\
\hline \multicolumn{5}{|c|}{ Storage period/(Months) } & \\
\hline 0 & $6.09 \pm 0.01^{\mathrm{aB}}$ & $6.08 \pm 0.02^{\mathrm{aB}}$ & $5.93 \pm 0.02^{\mathrm{bB}}$ & $5.71 \pm 0.01^{\mathrm{cB}}$ & $* *$ \\
\hline 6 & $6.09 \pm 0.12^{\mathrm{aB}}$ & $6.03 \pm 0.10^{\mathrm{aB}}$ & $5.90 \pm 0.12^{\mathrm{aB}}$ & $5.96 \pm 0.12^{\mathrm{aB}}$ & NS \\
\hline 12 & $6.32 \pm 0.12^{\mathrm{cA}}$ & $6.57 \pm 0.15^{\mathrm{bcA}}$ & $7.05 \pm 0.43^{\mathrm{aA}}$ & $6.78 \pm 0.12^{\mathrm{abA}}$ & $*$ \\
\hline P-level & NS & *** & $* *$ & $* *$ & \\
\hline \multicolumn{6}{|c|}{ C18:0 } \\
\hline $\mathbf{0}$ & $3.17 \pm 0.03^{\mathrm{aA}}$ & $3.15 \pm 0.02^{\mathrm{aA}}$ & $3.18 \pm 0.02^{\mathrm{aA}}$ & $3.17 \pm 0.03^{\mathrm{aA}}$ & NS \\
\hline 6 & $2.83 \pm 0.15^{\mathrm{aB}}$ & $2.90 \pm 0.21^{\mathrm{aA}}$ & $3.07 \pm 0.04^{\mathrm{aB}}$ & $2.93 \pm 0.11^{\mathrm{aB}}$ & NS \\
\hline 12 & $2.57 \pm 0.03^{\mathrm{bC}}$ & $2.60 \pm 0.11^{\mathrm{abB}}$ & $2.66 \pm 0.21^{\mathrm{abB}}$ & $2.81 \pm 0.05^{\mathrm{aB}}$ & NS \\
\hline P-level & $* *$ & $* *$ & $* *$ & $* *$ & \\
\hline \multicolumn{6}{|c|}{ C18:1 } \\
\hline $\mathbf{0}$ & $43.52 \pm 0.02^{\mathrm{bB}}$ & $43.68 \pm 0.02^{\mathrm{aB}}$ & $43.41 \pm 0.04^{\mathrm{cB}}$ & $42.96 \pm 0.11^{\mathrm{aB}}$ & $* *$ \\
\hline 6 & $42.88 \pm 0.27^{\mathrm{aC}}$ & $43.14 \pm 0.19^{\mathrm{aB}}$ & $43.14 \pm 0.46^{\mathrm{aB}}$ & $43.01 \pm 0.24^{\mathrm{aB}}$ & NS \\
\hline 12 & $46.53 \pm 0.20^{\mathrm{aA}}$ & $46.48 \pm 0.69^{\mathrm{aA}}$ & $46.74 \pm 0.90^{\mathrm{aA}}$ & $46.23 \pm 0.06^{\mathrm{aA}}$ & NS \\
\hline P-level & $* *$ & *** & $* *$ & ** & \\
\hline \multicolumn{6}{|c|}{ C18:2 } \\
\hline $\mathbf{0}$ & $48.19 \pm 0.11^{\mathrm{cA}}$ & $48.06 \pm 0.04^{\mathrm{dA}}$ & $48.53 \pm 0.03^{\mathrm{bA}}$ & $48.94 \pm 0.04^{\mathrm{aA}}$ & $* *$ \\
\hline 6 & $48.20 \pm 0.26^{\mathrm{aA}}$ & $47.93 \pm 0.28^{\mathrm{aA}}$ & $47.88 \pm 0.30^{\mathrm{aA}}$ & $48.10 \pm 0.34^{\mathrm{aB}}$ & NS \\
\hline 12 & $44.58 \pm 0.30^{\mathrm{aB}}$ & $44.36 \pm 0.94^{\mathrm{aB}}$ & $43.55 \pm 0.70^{\mathrm{aB}}$ & $44.18 \pm 0.22^{\mathrm{a} C}$ & NS \\
\hline P-level & $* *$ & $* *$ & $* *$ & $* *$ & \\
\hline
\end{tabular}

${ }^{a b c}$ Means values in the same row not sharing a superscript are significantly different.

${ }^{A B C}$ Means values in the same column not sharing a superscript are significantly different.

NS: not significant.

* Significant at $\mathrm{p}<0.05$.

** Significant at $\mathrm{p}<0.01$

There is a significantly increase $(p<0.05)$ in the concentration of total unsaturated fatty acids in sunflower seed oil while total saturated fatty acids have been significantly $(\mathrm{p}<0.05)$ reduced as a result of the irradiation process. Also, the ratio between total unsaturated and saturated fatty acids (TU/ TS) was 9.90 for the control sunflower oil seeds. There are slight differences in TU/TS values between oil extracted from irradiated and un-irradiated seeds, but sometime significant $(\mathrm{p}<0.05)$, while it increased gradually in parallel with the irradiation doses (Table 4).

The ratio of total unsaturated over total saturated (TUSFA/TSFA) was used to predict the shelf-life of seeds: indicating that the lower the ratio, the longer was product shelf-life [30]. In the present study, when the analysis was taken immediately after irradiation, these ratios were 9.90, 9.95, 10.09 and 10.35 for oil extracted from sunflower seed treated with 0, 3, 6 and $9 \mathrm{kGy}$, respectively. After 12 months of storage, the TUSFA/TSFA ratio was $10.25,9.91,9.30$ and 9.43 for oil extracted from sunflower seed treated with $0,3,6$ and $9 \mathrm{kGy}$, respectively (Table 4).

Table 4: Effects of gamma-irradiation and storage period on total saturated fatty acids (SFA) and unsaturated fatty acids (USFA) of Sunflower oil.

\begin{tabular}{|c|c|c|c|c|c|}
\hline Treatment & Control & $3 \mathrm{KGY}$ & $6 \mathrm{KGY}$ & $9 \mathrm{KGY}$ & $\begin{array}{l}\text { P- } \\
\text { level }\end{array}$ \\
\hline \multicolumn{3}{|c|}{ Storage period/(Months) } & \multicolumn{3}{|c|}{ SFA } \\
\hline 0 & $9.26 \pm 0.02^{\mathrm{bA}}$ & $9.22 \pm 0.02^{\mathrm{cA}}$ & $9.11 \pm 0.03^{\mathrm{dB}}$ & $9.88 \pm 0.02^{2 \mathrm{~A}}$ & $* *$ \\
\hline 6 & $8.92 \pm 0.07^{\mathrm{aB}}$ & $8.93 \pm 0.30^{\mathrm{aA}}$ & $8.98 \pm 0.15^{\mathrm{aB}}$ & $8.89 \pm 0.12^{\mathrm{aC}}$ & NS \\
\hline 12 & $8.89 \pm 0.09^{\mathrm{aB}}$ & $9.17 \pm 0.25^{\mathrm{aA}}$ & $9.72 \pm 0.30^{\mathrm{bA}}$ & $9.59 \pm 0.16^{\mathrm{bB}}$ & ** \\
\hline P-level & $* *$ & NS & $* *$ & $* *$ & \\
\hline \multicolumn{6}{|c|}{ USFA } \\
\hline 0 & $91.71 \pm 0.12^{\mathrm{cA}}$ & $91.73 \pm 0.06 \mathrm{~b}^{\mathrm{cA}}$ & $91.94 \pm 0.02^{\mathrm{aA}}$ & $91.90 \pm 0.14^{\mathrm{abA}}$ & NS \\
\hline 6 & $91.08 \pm 0.07^{\mathrm{a}}$ & $91.07 \pm 0.30^{\mathrm{aB}}$ & $91.02 \pm 0.16^{\mathrm{aB}}$ & $91.11 \pm 0.12^{\mathrm{aB}}$ & NS \\
\hline 12 & $91.11 \pm 0.10^{\mathrm{bB}}$ & $90.83 \pm 0.25^{\mathrm{aB}}$ & $90.28 \pm 0.29^{c \mathrm{C}}$ & $90.41 \pm 0.17^{\mathrm{c} C}$ & $* *$ \\
\hline P-level & $* *$ & $* *$ & $* *$ & $* *$ & \\
\hline \multicolumn{6}{|c|}{ USFA/SFA } \\
\hline 0 & $9.90 \pm 0.03^{\mathrm{dB}}$ & $9.95 \pm 0.02^{\mathrm{cA}}$ & $10.09 \pm 0.03^{\mathrm{bA}}$ & $10.35 \pm 0.04^{\mathrm{aA}}$ & $* *$ \\
\hline 6 & $10.21 \pm 0.09^{\mathrm{aA}}$ & $10.21 \pm 0.39^{\mathrm{aA}}$ & $10.14 \pm 0.19^{\mathrm{aA}}$ & $10.25 \pm 0.15^{\mathrm{aA}}$ & NS \\
\hline 12 & $10.25 \pm 0.12^{\mathrm{aA}}$ & $9.91 \pm 0.30^{\mathrm{aA}}$ & $9.30 \pm 0.32^{\mathrm{bB}}$ & $9.43 \pm 0.17^{\mathrm{bB}}$ & $*$ \\
\hline P-level & $* *$ & NS & $* *$ & $* *$ & \\
\hline \multicolumn{6}{|c|}{$\begin{array}{l}\text { abc Means values in the same row not sharing a superscript are significantly } \\
\text { different. } \\
\text { ABC Means values in the same column not sharing a superscript are } \\
\text { significantly different. } \\
\text { NS: not significant. } \\
\text { * Significant at } p<0.05 \text {. } \\
\text { * Significant at } p<0.01 \text {. }\end{array}$} \\
\hline
\end{tabular}

Effects of gamma-irradiation on fatty acid of peanut seed oil

The fatty acid content of total lipid extracted from nonirradiated peanut oil is shown in Figure 3. Data of fatty acid composition of oil extracts from irradiated and non-irradiated (control) peanut seed samples, which can be used to evaluate its stability and nutritional quality, is shown in Table 5. Three major fatty acids, namely, palmitic (C16:0), oleic (C18:1) and linoleic $(\mathrm{C} 18: 2)$ were found in peanut seeds oil and they constituted more than $97 \%$ of the total amount. The peanut seed oil contained $13.30 \%$ saturated fatty acids, with the major one being palmatic acid $10.82 \%$ followed by stearic acid $(2.37 \%)$, while it was high in un-saturated fatty acids with a total content of $86.7 \%$. Shin et al. [31] and De Camargo et al. [10] reported that palmitic acid (C16:0) ranged from $5.31 \%$ to $11.49 \%$; stearic 
acid (C18:0), $1.46 \%$ to $4.76 \%$; oleic acid (C18:1), $44.78 \%$ to 82.17\%; and linoleic acid (C18:2) $2.85 \%$ to 33.92 . This is in good agreement with the findings of Shin et al. [31] whose data confirm that fatty acid composition can be different, even within the same cultivar and the same harvest year.

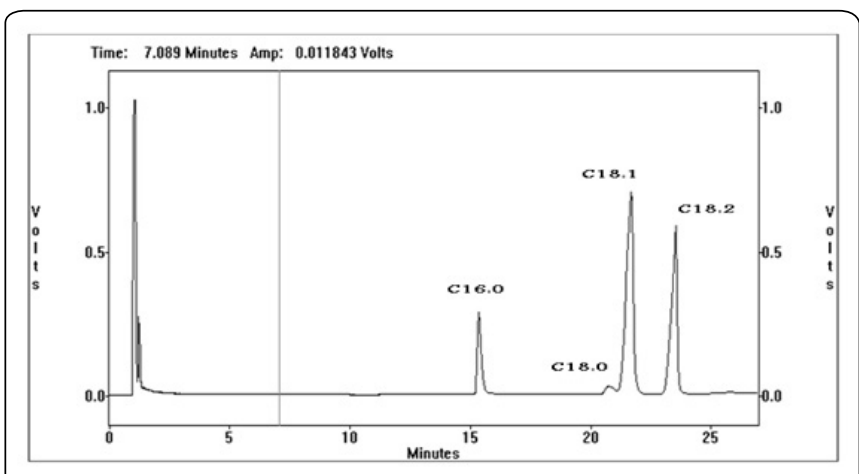

Figure 3: Fatty acids contents of peanut seed oil.

\begin{tabular}{|c|c|c|c|c|c|}
\hline Treatment & Control & $3 \mathrm{KGY}$ & $6 \mathrm{KGY}$ & $9 \mathrm{KGY}$ & $\begin{array}{l}\text { P- } \\
\text { level }\end{array}$ \\
\hline \multicolumn{6}{|c|}{ Storage period/(Months) } \\
\hline $\mathbf{0}$ & $10.82 \pm 0.15^{\mathrm{aB}}$ & $10.69 \pm 0.04^{\mathrm{B}}$ & $10.82 \pm 0.07^{\mathrm{a}}$ & $10.75 \pm 0.07^{\mathrm{aB}}$ & NS \\
\hline 6 & $9.36 \pm 0.13^{\mathrm{bC}}$ & $9.64 \pm 0.07 \mathrm{ac}$ & $9.79 \pm 0.07^{\mathrm{ac}}$ & $9.66 \pm 0.02^{\mathrm{aC}}$ & ** \\
\hline 12 & $11.71 \pm 0.04^{\mathrm{aA}}$ & $11.75 \pm 0.12^{2 \mathrm{~A}}$ & $11.77 \pm 0.05^{\mathrm{aA}}$ & $11.75 \pm 0.03^{\mathrm{aA}}$ & NS \\
\hline P-level & NS & $* *$ & $* *$ & ** & \\
\hline \multicolumn{6}{|c|}{ C18:0 } \\
\hline $\mathbf{0}$ & $2.37 \pm 0.11^{\mathrm{aB}}$ & $2.32 \pm 0.06^{\mathrm{abC}}$ & $2.31 \pm 0.06^{\mathrm{abB}}$ & $2.23 \pm 0.03^{\mathrm{bB}}$ & NS \\
\hline 6 & $2.71 \pm 0.09^{\mathrm{aA}}$ & $2.69 \pm 0.05^{\mathrm{aA}}$ & $2.40 \pm 0.10^{\mathrm{bAB}}$ & $2.27 \pm 0.13^{\mathrm{bB}}$ & ** \\
\hline 12 & $2.27 \pm 0.05^{\mathrm{cB}}$ & $2.44 \pm 0.05^{\mathrm{bcB}}$ & $2.92 \pm 0.49^{\mathrm{abA}}$ & $3.02 \pm 0.26^{\mathrm{aA}}$ & $*$ \\
\hline P-level & $* *$ & $* *$ & NS & ** & \\
\hline \multicolumn{6}{|c|}{ C18:1 } \\
\hline $\mathbf{0}$ & $49.69 \pm 0.50^{2 \mathrm{~A}}$ & $49.55 \pm 0.18^{\mathrm{abB}}$ & $49.43 \pm 0.14^{\mathrm{abB}}$ & $49.02 \pm 0.41^{\mathrm{bB}}$ & NS \\
\hline 6 & $50.24 \pm 0.11^{\mathrm{abA}}$ & $50.29 \pm 0.10^{2 A}$ & $50.14 \pm 0.27^{\mathrm{abA}}$ & $49.97 \pm 0.16^{\mathrm{bA}}$ & NS \\
\hline 12 & $50.19 \pm 0.06^{\mathrm{aA}}$ & $49.38 \pm 0.29^{\mathrm{bB}}$ & $49.81 \pm 0.19^{\mathrm{abAB}}$ & $49.75 \pm 0.51^{\mathrm{bAB}}$ & NS \\
\hline P-level & NS & $* *$ & ${ }^{*}$ & $*$ & \\
\hline \multicolumn{6}{|c|}{ C18:2 } \\
\hline $\mathbf{0}$ & $36.90 \pm 0.65^{\mathrm{aB}}$ & $37.29 \pm 0.14^{\mathrm{aB}}$ & $37.29 \pm 0.18^{\mathrm{aB}}$ & $37.87 \pm 0.40^{\mathrm{aB}}$ & NS \\
\hline 6 & $37.53 \pm 0.27^{\mathrm{aB}}$ & $37.25 \pm 0.02^{2 \mathrm{~B}}$ & $37.55 \pm 0.17^{\mathrm{aB}}$ & $37.97 \pm 0.13^{\mathrm{aB}}$ & ** \\
\hline 12 & $35.65 \pm 0.09^{\mathrm{bA}}$ & $36.26 \pm 0.45^{\mathrm{bA}}$ & $35.32 \pm 0.48^{\mathrm{aA}}$ & $35.32 \pm 0.68^{\mathrm{aA}}$ & NS \\
\hline P-level & $*$ & ${ }^{* *}$ & $* *$ & $* *$ & \\
\hline \multicolumn{6}{|c|}{$\begin{array}{l}\text { abc Means values in the same row not sharing a superscript are significantly } \\
\text { different. } \\
\text { ABC Means values in the same column not sharing a superscript are } \\
\text { significantly different. } \\
\text { NS: not significant. } \\
\text { * Significant at } p<0.05 \text {. } \\
\text { * Significant at } p<0.01 \text {. }\end{array}$} \\
\hline
\end{tabular}

The high content of monounsaturated fatty acid (MUFA) particularly oleic acid (C18:1) (49.69\%) is associated with a low incidence of coronary heart disease (CHD) because it decreases total cholesterol and low-density lipoprotein cholesterol [32]. However, unsaturated fatty acids like oleic acids, linoleic and linolenic fatty acids are fundamental in the human diet as they can't be produced by animal metabolism [33].

The oleic to linoleic acid $(\mathrm{O} / \mathrm{L})$ ratio is a quality index employed for the determination of genetic peanut characteristics classified as normal, mid and high oleic types, ranging from 1.0 to $1.5 ; 1.5$ to 9.0 , and above 9.0 , respectively [31]. The present study was carried out with normal oleic peanuts $(\mathrm{O} / \mathrm{L}=1.35)$. The ratio of oleic and linoleic acid $(\mathrm{O} / \mathrm{L})$ is also important features in determining peanut seed shelf-life and oil stability.

Results show a slight increase in the relative percentages of the total saturated fatty acids (TF) at doses of 3, 6 and $9 \mathrm{kGy}$, and slight decrease in the relative percentages of the total unsaturated fatty acids (TUF) at doses of 3 and $6 \mathrm{kGy}$. The present finding agrees with those obtained by Afify et al. [7] on peanut seed treated with dose up to $7.5 \mathrm{kGy}$. Similar results were reported by Olotu et al. [2] for fatty acid profile of African oil bean seeds treated with $10 \mathrm{kGy}$ of gammairradiation. Golge and Ova [34] reported that the effect of irradiation at dose up to $5 \mathrm{kGy}$ on palmatic, stearic, oleic and linleic acids was statistically insignificant $(p>0.05)$ for pine nut. Brewer [35] reported that the lipids that are affected by irradiation are mainly the two or more double bonded polyunsaturated fatty acids. On the other hand, there was almost no change in fatty acid composition of peanut oil when prepared by microwave processing until $12 \mathrm{~min}$ [36].

\section{Effects of storage times on fatty acid content of sesame sunflower and peanut seeds oil}

The effects of storage time on individual fatty acids of sesame sunflower and peanut seeds oil are shown in Tables 1 , 3 and 5 respectively, while the effect of storage time on total saturated (S), total unsaturated (US) and US/S ratio of sesame sunflower and peanut seeds oil are show in Tables 2, 4 and 6 respectively. In general, storage time caused a significant $(p<0.05)$ difference between the fatty acid composition of the sesame sunflower and peanut seeds oil. The presented data show an increase in the percentage of the total saturated fatty acids and decrease in the percentage of the total unsaturated fatty acids of peanut seed oil (Table 6). While, the data also shown a decrease in the percentage of the total saturated fatty acids and increased in the percentage of the total unsaturated fatty acids of sunflower seed oil (Table 4). Moreover, the total saturated and total unsaturated fatty acids remained unaffected during storage (Table 2). The increase in SFA and the decrease in USFA during storage was probably due to the preferential cleaving double bonds. Storage may cause the saturation of double bonds of palmitoleic (C16:1), linoleic (C18:2) and linolenic acid (C18:3). Mexis et al. [37], who reported an increase in saturated fatty acids along a decrease in unsaturated fatty acids in ground almonds during storage. The decrease in the unsaturated fatty acid content and the concomitant increase in the saturated fatty acid content are explained by De Camargo et al. [10], who stated that the ratio of the oxidation rates of stearic, oleic, linoleic and linolenic acids was 1: 10: 100: 200. Another study suggested that, the decrease in unsaturated fatty acids during oil storage is mainly due to a molecular structure change in fatty acids [38]. 
Table 6: Effects of gamma-irradiation and storage period on total saturated fatty acids (SFA) and unsaturated fatty acids (USFA) of Peanut oil.

\begin{tabular}{|c|c|c|c|c|c|}
\hline Treatment & Control & 3 KGY & $6 \mathrm{KGY}$ & 9 KGY & $\begin{array}{l}\text { P- } \\
\text { level }\end{array}$ \\
\hline \multicolumn{3}{|c|}{ Storage period/(Months) } & \multicolumn{3}{|c|}{ SFA } \\
\hline $\mathbf{0}$ & $13.30 \pm 0.23^{\mathrm{a}}$ & $13.10 \pm 0.08^{\mathrm{aB}}$ & $13.23 \pm 0.14^{\mathrm{aB}}$ & $13.06 \pm 0.07^{\mathrm{aB}}$ & NS \\
\hline 6 & $12.16 \pm 0.18^{\mathrm{abC}}$ & $12.40 \pm 0.10^{\mathrm{aC}}$ & $12.25 \pm 0.17^{\mathrm{abC}}$ & $12.01 \pm 0.14^{\mathrm{bC}}$ & NS \\
\hline 12 & $14.08 \pm 0.05^{\mathrm{bA}}$ & $14.29 \pm 0.16^{\mathrm{abA}}$ & $14.79 \pm 0.53^{\mathrm{aA}}$ & $14.85 \pm 0.24^{\mathrm{aA}}$ & $*$ \\
\hline P-level & $* *$ & *k & $* *$ & *** & \\
\hline \multicolumn{6}{|c|}{ USFA } \\
\hline $\mathbf{0}$ & $86.70 \pm 0.23^{\mathrm{bB}}$ & $86.90 \pm 0.08^{\mathrm{bB}}$ & $86.77 \pm 0.14^{\mathrm{bB}}$ & $86.94 \pm 0.07^{\mathrm{aB}}$ & NS \\
\hline 6 & $87.84 \pm 0.18^{\mathrm{aA}}$ & $87.75 \pm 0.10^{\mathrm{aA}}$ & $87.75 \pm 0.17^{\mathrm{aA}}$ & $87.99 \pm 0.14^{\mathrm{aA}}$ & NS \\
\hline 12 & $85.92 \pm 0.05^{\mathrm{aC}}$ & $85.72 \pm 0.16^{\mathrm{abC}}$ & $85.21 \pm 0.53^{\mathrm{bcc}}$ & $85.15 \pm 0.24^{\mathrm{c}}$ & $*$ \\
\hline P-level & ** & **k & $* *$ & $* *$ & \\
\hline \multicolumn{6}{|c|}{ USFA/SFA } \\
\hline $\mathbf{0}$ & $6.52 \pm 0.13^{\mathrm{aB}}$ & $6.64 \pm 0.05^{\mathrm{aB}}$ & $6.56 \pm 0.08^{\mathrm{aB}}$ & $6.66 \pm 0.04^{4 \mathrm{~B}}$ & NS \\
\hline 6 & $7.22 \pm 0.12^{\mathrm{abA}}$ & $7.06 \pm 0.07^{\mathrm{bA}}$ & $7.16 \pm 0.11^{\mathrm{abA}}$ & $7.33 \pm 0.10^{\mathrm{aA}}$ & NS \\
\hline 12 & $6.10 \pm 0.02^{\mathrm{aC}}$ & $6.00 \pm 0.08^{\mathrm{cC}}$ & $5.77 \pm 0.25^{\mathrm{bC}}$ & $5.73 \pm 0.11^{\mathrm{bC}}$ & $*$ \\
\hline P-level & $* *$ & $* *$ & $* *$ & $* *$ & \\
\hline \multicolumn{6}{|c|}{$\mathrm{O} / \mathrm{L}$} \\
\hline $\mathbf{0}$ & $1.35 \pm 0.04^{\mathrm{aB}}$ & $1.33 \pm 0.01^{\mathrm{abB}}$ & $1.33 \pm 0.01^{\mathrm{abB}}$ & $1.30 \pm 0.02^{\mathrm{bB}}$ & NS \\
\hline 6 & $1.34 \pm 0.01^{1 \mathrm{~B}}$ & $1.35 \pm 0.002^{\mathrm{aAB}}$ & $1.34 \pm 0.01^{\mathrm{aA}}$ & $1.32 \pm 0.01^{\mathrm{bB}}$ & $*$ \\
\hline 12 & $1.41 \pm 0.01^{\mathrm{aA}}$ & $1.36 \pm 0.03^{\mathrm{bA}}$ & $1.41 \pm 0.02^{\mathrm{aB}}$ & $1.41 \pm 0.04^{\mathrm{aA}}$ & NS \\
\hline P-level & $*$ & NS & ** & ** & \\
\hline \multicolumn{6}{|c|}{$\begin{array}{l}\text { abc Means values in the same column not sharing a superscript are significantly } \\
\text { different. }\end{array}$} \\
\hline \multicolumn{6}{|c|}{$\begin{array}{l}\mathrm{ABC} \text { Means values in the same row not sharing a superscript are significantly } \\
\text { different. }\end{array}$} \\
\hline \multicolumn{6}{|c|}{ NS: not significant. } \\
\hline \multicolumn{6}{|c|}{ * Significant at $\mathrm{p}<0.05$} \\
\hline \multicolumn{6}{|c|}{ ** Significant at $\mathrm{p}<0.01$. } \\
\hline
\end{tabular}

\section{Conclusion}

Sesame, sunflower and peanut seed oil is of unsaturated type and that oil can be classified in the oleic-linoleic acid group. Irradiation of seeds with medium doses ( 3 to $9 \mathrm{kGy}$ ) that are recommended in the literature for eliminating microorganisms did not affect fatty acids profiles and retained polyunsaturated fatty acids present in oil extracted from sesame, sunflower and peanut seeds.

\section{Acknowledgements}

The author wishes to express deep appreciation to the Director General of the Atomic Energy Commission of Syria (AECS) and the staff of the division of food irradiation.

\section{Conflict of Interest}

The author reports no conflicts of interest. The author alone is responsible for the content and writing of the manuscript.

\section{References}

1. Adewuyi A, Rachapudi BN, Prasad BV, Oderinde R. 2010. Oil composition, mineral nutrient and fatty acid distribution in the lipid classes of underutilized oils of Trilepisium madagascariense and Antiaris africana from Nigeria. Food Res Int 43(3): 665-670. doi: 10.1016/j. foodres.2009.12.007
2. Olotu I, Enujiugha V, Obadina A, Owolabi, K. 2014. Fatty acid profile of gamma irradiated and cooked African oil bean seed (Pentaclethra macrophylla Benth). Food Sci Nutr 2(6): 786-791. doi: 10. 1002/fsn3. 176: $1-6$

3. Haghparast S, Kashiri H, Shabanpour B, Pahlavani MH. 2010. Antioxidant properties of sodium acetate, sodium citrate and sodium lactate on lipid oxidation in rainbow trout (Oncorbynchus mykiss) sticks during refrigerated storage $\left(4{ }^{\circ} \mathrm{C}\right)$. Iranian Journal of Fisheries Science 9(1): 73-86.

4. Guinda A, Dobarganes MC, Ruiz-Mendez MV, Mancha M. 2003. Chemical and physical properties of a sunflowers oil with high levels of oleic and palmitic acids. Eur J Lipid Sci Technol 105(3-4): 130-137. doi: 10.1002/ejlt.200390028

5. McKevith B. 2005. Nutritional aspects of oilseeds. Nutr Bull 30(1): 1326. doi: 10.1111/j.1467-3010.2005.00472.x

6. Min DB, Boff JF. 2001. Lipid oxidation of edible oil. In: Akoh CC, Min DB (eds) Food Lipids. Marcel Dekker, New York, USA, pp 335-563.

7. Afify AMR, Rashed MM, Ebtesam AM, El-Beltagi HS. 2013. Effect of gamma radiation on the lipid profiles of soybean, peanut and sesame seed oils. Grasas Y Aceites 64(4): 356-368. doi: 10.3989/gya.119712

8. Al-Bachir M. 2004. Effect of gamma irradiation on fungal load, chemical and sensory characteristics of walnuts (Juglans regia L.). J Stored Prod Res 40(4): 355-362. doi: 10.1016/S0022-474X(03)00030-4

9. AL-Bachir M, Zeinou R. 2014. Effect of gamma irradiation on the microbial load, chemical and sensory properties of goat meat. Acta Aliment 43(2): 72-80. doi: 10.1556/AAlim.43.2014.2.10

10. De Camargo AC, Souza Vieira TMF, Arce MABR, Alencar SM, Domingues MAC, et al. 2012. Gamma radiation induced oxidation and tocopherols decrease in in-shell, peeled and blanched peanuts. Int J Mol Sci 13(3): 2827-2845. doi: 10.3390/ijms13032827

11. AL-Bachir M. 2014. Physicochemical properties of oil extracts from gamma irradiated almond (Prunus amygdalus L.). Innov Rom Food Biotech 14: 37-45.

12. AL-Bachir M. 2015. Studies on the physicochemical characteristics of oil extracted from gamma irradiated pistachio (Pistacia vera L.). Food Chem 167: 175-179. doi: 10.1016/j.foodchem.2014.06.020

13. AL-Bachir M. 2015. Quality characteristics of oil extracted from gamma irradiated peanut (Archis hypogea L.). Radiat Phys Chem Oxf Engl 106: 56-60. doi: 10.1016/j.radphyschem.2014.06.026

14. Lutfullah G, Zeb A, Ahmad T, Atta S, Bangash FK. 2003. Changes in the quality of sunflower and soybean oils induced by high doses of gamma radiations. J Chem Soc Pak 25(4): 269-275.

15. AOAC. 2010. Official Methods of Analysis. Association of Official Analytical Chemists, $15^{\text {th }}$ edition, Washington D.C, USA.

16. Snedecor G, Cochran W. 1988. Statistical methods. The Iowa State University Press, Ames, Iowa, USA pp 221-221.

17. Zouumpoulakis P, Sinanoglou VJ, Batrinou A, Strati IF, MiniadisMeimaroglou S, et al. 2012. Combined methodology to detect gamma irradiated white sesame seeds and evaluate the effects on fat content, physiochemical properties and protein allergenicity. Food Chem 131(2): 713-721. doi: 10.1016/j.foodchem.2011.09.049

18. Uznu B,Arslan C, Karhan M,Toker C.2007. Fat and fatty acids of white lupin (Lupinus albus L.) in comparison to sesame (Sesamum indicum L.). Food Chem 102(1): 45-49. doi: 10.1016/j.foodchem.2006.03.059

19. Nzikou JM, Matos L, Bouanga-Kalou G, Ndangui CB, Pambou-Tobi, et al. 2009. Chemical composition on the seeds and oil of sesame (Sesamum indicum L.) grown in Congo-Brazzaville. Adv J Food Sci Technol 1(1): 6-11.

20. Elleuch M, Besbes S, Roiseux O, Blecker C, Attia H. 2007. Quality characteristics of sesame seeds and by products. Food Chem 103(2): 641650. doi: 10.1016/j.foodchem.2006.09.008

21. Bensmira M, Jiang B, Nsabimana C, Jian T. 2007. Effect of Lavender and Thyme incorporation in sunflower seed oil its resistance to 
frying temperatures. Food Res Int 40(3): 341-346. doi: 10.1016/j foodres.2006.10.004

22. Xiang-Zhen S, En-jie D, Zheng Z, Ji N, Wen-wen Ma, et al. 2014. Effects of UV-irradiation detoxification in a photo-degradation reactor on quality of peanut oil. Int Food Res J 21(6): 2311-2314.

23. Barreira JCM, Antonio AL, Gunaydi TT, Alkan H, Bento A, et al.2012. Chemometric characterization of gamma irradiation chestnuts from Turkey. Radiat Phys Chem Oxf Engl 81(9): 1520-1524. doi 10.1016/j. radphyschem.2012.01.005.

24. Mexis SF, Badeka AV, Chouliara E, Riganakos KA, Kontominas MG. 2009. Effect of $\gamma$-irradiation on the physicochemical \& sensory properties of raw unpeeled almond kernels (Prunus dulcis). Innov Food Sci Emerg Technol 10(1): 87-92. doi: 10.1016/j.ifset.2008.09.001

25. Ogungbenle HN, Afolayan MF. 2015. Physical and chemical characterization of roasted cashew nut (Anacardium occidentale) flour and oil. International Journal of Food Science and Nutrition Engineering 5(1): 1-7. doi: 10.5923/j.food.20150501.01

26. Samarth NB, Mahanwar PA. 2015. Modified vegetable oil based additives as a future polymeric materials- review. Open Journal of Organic Polymer Materials 5(1): 1-22. doi: 10.4236/ojopm.2015.51001

27. Makhoul H, Ghaddar T, Toufeili I. 2006. Identification of some rancidity measures at the end of the shelf life of sunflower oil. Eur J Lipid Sci Technol 108(2): 143-148. doi: 10.1002/ejlt.200500262

28. Hosein MH, Ghavami M, Heidary-Nasab A, Gharachorloo M. 2014. The effect of bleaching process on the physical and chemical characteristics of canola and sunflower seed oil. Journal of Food Bioscience and Technology 4(2): 41-44.

29. Mahrous SR. 2007. Chemical properties of Aspergillus flafus -infected soybean seeds exposed to gamma irradiation during storage. Int J Agric Biol 9(2): 231-238.
30. Fokou E, Achul MB, Kanscil G, Ponkal R, Fotso M, et al. 2009. Chemical properties of some cucurbitaceae oils from Cameroon. Pakistan Journal of Nutrition 8(9): 1325-1334. doi: 10.3923/pjn.2009.1325.1334

31. Shin EC, Craft BD, Pegg RB, Phillips RD, Eitenmiller RR. 2010. Chemometric approach to fatty acid profiles in Runner-type peanut cultivars by principal component analysis (PCA). Food Chem 119(3): 1262-1270. doi: 10.1016/j.foodchem.2009.07.058

32. Dennys ECC, Andre GVC, Mariado CGP, Marco TCS, Neuza MBC. 2006. Liquid profile of rate fed diets based on flaxseed, peanut, trout, or chicken skin. Nutrition 22(2): 197-205. doi: 10.1016/j.nut.2005.09.003

33. El-Sayed SS. 2008. Effect of heat stress on phytochemical composition of peanut seedling. Res J Agric Biol Sci 4(2): 167-174.

34. Golge E, Ova G. 2008. The effects of food irradiation on quality of pine nut kernels. Radiat Phys Chem Oxf Engl 77(3): 365-369. doi: 10.1016/j. radphyschem.2007.06.005

35. Brewer MS. 2009. Irradiation effects on meat flavor: a review. Meat Sci 81(1): 1-14. doi: 10.1016/j.meatsci.2008.07.011

36. Yoshida H, Hirooka Y, Tomiyama Y, Nagamizu T, Mizushina Y. 2005. Fatty acid distributions of triacyglycerols and phospholipids in peanut seeds (Archis hypogaea L.) following microwave treatment. J Food Compost Anal 18(1): 3-14. doi: 10.1016/j.jfca.2003.12.004

37. Mexis SF, Badeka AV, Kontominas MG. 2009. Quality evaluation of raw ground almond kernels (Prunu dulcis): Effect of active and modified atmosphere packaging, container oxygen barrier and storage conditions. Innov Food Sci Emerg Technol 10(4): 580-589. doi: 10.1016/j. ifset.2009.05.002

38. Arici M, Ferya AC, Umit G. 2007. Effect of gamma radiation on microbiological and oil properties of black cumin (Nigalla sativa L.). Grasas y Aceites 58(4): 339-343. doi: 10.3989/gya.2007.v58.i4.444 